\title{
ANALISIS KANDUNGAN GIZI PRODUK OLAHAN SAYUR LEBUI
}

\author{
[Analysis of Lebui Nutrition]
}

\author{
Agus Dwi Ananto* \\ Program Studi Farmasi Universitas Mataram \\ *email: agus_da@unram.ac.id
}

Diterima 5 September 2017/ Disetujui 16 November 2017

\begin{abstract}
The high prevalence of malnutrition reflected low food security in West Nusa Tenggara Province. Nutritional, security, sociocultural, and diversification in the processing and utilization of food that has not been optimal to be the cause of it. Lebui [Glycine max (L.) Merril] as a typical vegetable processed product of Lombok island can be one of alternative of food reinforcement. This aims of this research was to determined the water content, ash and anthocyanin processed vegetable products in quantitative and sensory. Evaluation of nutritional content using proximate analysis while receiving aspect using favorite test. The results showed that water, ash, and anthocyanin levels in the samples were $11.366 \% \mathrm{w} / \mathrm{w}$, $4.116 \% \mathrm{w} / \mathrm{w}, 46.757 \mathrm{mg} / 100 \mathrm{~g}$ respectively while in the processed products had similar results with seeds with the decreasing trend of anthocyanin content. Preferably test shows organoleptically more vegetable variants more desirable from the aspects of taste, texture, and aroma. Processed vegetable products have higher nutritional content and are preferred by consumers so that it can be further developed as a diversificated of food products.
\end{abstract}

Keywords: hedonic test, processed vegetable product, proximate analysis

\section{ABSTRAK}

Angka prevalensi gizi buruk yang tinggi merefleksikan rendahnya ketahanan pangan di Provinsi Nusa Tenggara Barat. Aspek gizi, keamanan, sosiokultural, diversifikasi dalam pengolahan dan pemanfaatan pangan yang belum optimal menjadi faktor penyebab hal tersebut. Lebui [Glycine max (L.) Merril] sebagai produk olahan sayur khas pulau Lombok dapat menjadi salahsatu alternatif penguatan pangan. Penelitian ini bertujuan untuk mengetahui kadar air, abu dan antosianin produk olahan sayur lebui secara kuantitatif dan sensoris. Evaluasi kandungan gizi menggunakan analisa proksimat sementara aspek penerimaan menggunakan uji kesukaan. Hasil penelitian menunjukkan kadar air, abu, dan antosianin pada sampel berturut-turut sebesar $11,366 \% \mathrm{~b} / \mathrm{b}, 4,116 \% \mathrm{~b} / \mathrm{b}, 46,757 \mathrm{mg} / 100 \mathrm{~g}$ sementara pada produk olahan memiliki hasil yang serupa dengan biji lebui disertai dengan trend penurunan kadar antosianin. Uji kesukaan menunjukkan secara organoleptik varian sayur lebui lebih diminati dari aspek rasa, tekstur, dan aroma. Produk olahan sayur lebui memiliki kandungan gizi yang cukup tinggi dan lebih disukai konsumen sehingga dapat dikembangkan lebih lanjut sebagai diversifikasi produk pangan.

Kata kunci:analisa proksimat, produk olahan sayur lebui, uji kesukaan

\section{PENDAHULUAN}

Ketahanan pangan dan gizi merupakan salah satu indikator pencapaian kesejahteraan bangsa, dengan pangan rumah tangga yang cukup ditinjau secara kuantitas dan kualitas akan tercipta sumberdaya manusia handal dan berdaya saing dalam pembangunan jangka panjang. Ketahanan pangan dan gizi menjadi isu prioritas rencana kerja regional sebagaimana yang ditegaskan oleh Menteri Desa, Pembangunan Daerah Tertinggal, dan Transmigrasi pada sambutan Konferensi FAO di Malaysia padatanggal 11 Maret 2016.

Kasus gizi buruk masih ditemukan pada 55 anak di NTB hingga bulan Februari 2016, kenaikan yang cukup signifikan jika dibandingkan jumlah 33 kasus di tahun 2015. Data 24 Januari 2015 menunjukkan bahwa prevalensi gizi kurang di Provinsi Nusa Tenggara Barat (NTB) sebesar 25,7 \%, berada diatas prevalensi nasional dengan angka $19,6 \%$. Temuan ini mengindikasikan ketahanan pangan provinsi NTB sebagai salah satu faktor yang sinergis dengan ketahanan gizi masih belum optimal.

Empat aspek utama yang berperan sebagai hambatan dalam optimalisasi ketahanan pangan diantaranya yaitu gizi, keamanan, distribusi, sosiokultural, serta pemanfaatan pangan (Kemenristek, 2006). Diversifikasi pangan berbasis kearifan local merupakan salah satu solusi untuk mengatasi hambatan ketahanan pangan nasional. Jika 
kearifan tersebut dieksplorasi dengan system penjaminan kualitas yang baik (peningkatan nilait ambah, penyesuaian dengan standar kualitas pangan) akan menciptakan suatu system pangan berbasis komunitas, mendorong pengembangan desa melalui peningkatan pendapatan in situ dan akhirnya menciptakan ketahanan pangan.

Kedelai hitam atau lebui (G/ycine max (L.) Merill) telah lama dikonsumsi oleh masyarakat di pulau Lombok sebagai olahan produk pangan berupa sayur. Secara saintifik, kedelai hitam memiliki kandungan gizi yang tinggi dan efek farmakologis. Kadar protein kedelai hitam varietas Mallika memiliki nilai yang cukup tinggi sebesar 39,09\%. Kandungan asam amino glutamat kedelai hitam lebih tinggi dibandingkan dengan kedelai kuning varietas Grobogan dan impor (Nurrahman, 2015). Kadar antosianin dan senyawa fenolik kulit kedelai hitam berturutturut sebesar 1,36 dan 6,46 g/100 g (Astadi, 2009). Antosianin yang tinggi dalam kedelai hitam telah diteliti memiliki efek antiinflamasi, antiobesitas, dan memperbaiki hiperglisemia pada mencit diabetes. (Kwon, et.al, 2007 ;Nizamutdinovaet. al., 2009; Kurimoto, et.al., 2013).

Studi mengenai kandungan gizi lebui dan produk olahan sayur lebui masih terbatas. Demikian pula studi evaluasi tingkat penerimaan terhadap olahan produk sayur yang telah ada. Berdasarkan uraian tersebut penelitian ini bertujuan untuk mengevaluasi lebui dan ragam variasi olahan sayur berbahan dasar lebui secara kuantitatif dan sensoris sebagai pengembangan nutrasetikal berbasis kearifan lokal masyarakat Sasak di Pulau Lombok.

\section{BAHAN DAN METODE}

Penelitian ini merupakan studi eksperimen yang berfokus pada evaluasi kualitas kuantitatif, tersembunyi, dan sensoris hasil pengembangan olahan produk sayur lebui. Penelitian diselenggarakan di daerah Praya, Lombok Tengah dan beberapa laboratorium di lingkungan Universitas Mataram.

\section{Alat}

Alat dalam pembuatan ragam olahan sayur lebui, alu, batang pengaduk, blender,botol semprot, botol timbang, bulbus, cawan penguap, desikator, gelas kimia, gelas ukur, gelas kumur, krus,k uvet, lemari asam, labu Erlenmeyer, labu takar, lumpang, neraca analitik, oven, penjepit krus, pipet tetes, pipet volum, seperangkat alat spektrofotometer UV, seperangkat ala Soxhlet, tangas uap,tabung reaksi dan rak, sentrifugal, spatula, vorteks, wadah plastik.

\section{Bahan}

Akuades, asam trikloro asetat, asam klorida 2,5 N, asam sulfat pekat, bahan pembuatan ragam olahan sayurl ebui, biji lebui [Glycine max (L.) Merril], dietileter, etanol $95 \%$, Bovine Serum Albumin $5 \mathrm{mg} / \mathrm{mL}$, kertas saring, kertas timbang, larutan fenol $5 \%$, lembar kuesioner, lembar informed consent, natrium karbonat, petroleum eter, reagen Biuret.

\section{Sampel Uji}

Sampel uji yang dilibatkan dalam uji kesukaan berjumlah 75 orang panelis konsumen meliputi mahasiswa dan staf Program Studi Farmasi Universitas Mataram. Sampel uji memenuhi criteria inklusi dan eksklusi yang diadaptasi dari SNI 01-23462006.

\section{Penyiapan Bahan dan Ragam Olahan Produk}

Tumbuhan dan biji lebui [Glycine max (L.) Merril] diperoleh dari daerah Praya, Lombok Tengah. Sampel tumbuhan kemudian dideterminasi di Laboratorium Biologi FMIPA Universitas Mataram. Ragam produk olahan sayur lebui dibuat berdasarkan padau sulan formula sebagaimana yang disajikan dalam Tabel1.

\section{Analisis Proksimat dan Ultimat}

Analisis proksimat dan ultimat dilakukan meliputi parameter: kadar air, abu, karbohidrat, protein, lemak, dan antosianin. Akan tetapi, pada penelitian ini difokuskan pada parameter kadar air, abu dan antosianin saja. Kedua jenis analisis dilakukan pada sampel lebui dan varian produk olahan sayur lebui. Preparasi sampel dilakukan pada produk olahan untuk meminimalisasi gangguan matriks pada penentuan kadar analit.

\section{Penentuan Kadar Air}

Sejumlah bahan yang telah dihaluskan ditimbang dalam botol timbang yang telah ditimbang terlebih dahulu. Botol timbang berisi sampel dikeringkan dalam oven pada suhu $100-105{ }^{\circ} \mathrm{C}$ kemudian didinginkan dalam desikator dan ditimbang. Perlakuan diulangi sampai tercapai berat konstan yakni selisih 
penimbangan berturut-turut 0,2 $\mathrm{mg}$. Persentase kadar air ( $\%$ b/b) sampel selanjutnya dihitung (Sudarmadji, et. al. 2010; Nielsen, 2010 ${ }^{\text {b) }}$ ).

Tabel 1 Varian Usulan Formula Sayur Lebui

\begin{tabular}{|c|c|c|c|}
\hline Ragam & \multicolumn{2}{|c|}{ Formula dan Variasi } & Nilai Gizi \\
\hline $\begin{array}{l}\text { Sayur } \\
\text { Lebui } \\
\text { Daging } \\
\text { Sapi }\end{array}$ & $\begin{array}{l}\text { Lebui } 200 \\
\text { gram } \\
\text { Bawang } \\
\text { muda } \\
\text { Daging sapi } \\
250 \text { gram } \\
\text { Air } 2 \text { liter } \\
\text { Cabai rawit } 6 \\
\text { buah }\end{array}$ & $\begin{array}{l}\text { Bawang putih } \\
4 \text { siung } \\
\text { Bawang } \\
\text { merah } 6 \text { siung } \\
\text { Tomat } 2 \text { buah } \\
\text { Lengkuas } 2 \\
\text { cm } \\
\text { Garam dan } \\
\text { gula pasir qs }\end{array}$ & $\begin{array}{l}\text { Daging } \\
\text { sapi : } \\
\text { protein } 18,8 \\
\text { gram, air } \\
66,0 \text { gram, } \\
\text { dan lemak } \\
14,0 \text { gram }\end{array}$ \\
\hline $\begin{array}{l}\text { Sayur } \\
\text { Lebui } \\
\text { Labu } \\
\text { Kuning }\end{array}$ & $\begin{array}{l}\text { Lebui } 200 \\
\text { gram } \\
\text { Bawang } \\
\text { muda } \\
\text { Labu } \\
\text { kuning } 100 \\
\text { gram } \\
\text { Air } 2 \text { liter } \\
\text { Cabai rawit } 6 \\
\text { buah } \\
\text { Bawang } \\
\text { putih } 4 \text { siung } \\
\text { Bawang } \\
\text { merah } 6 \\
\text { siung } \\
\text { Tomat } 2 \\
\text { buah }\end{array}$ & $\begin{array}{l}\text { Salam } 2 \\
\text { lembar } \\
\text { Santan } 200 \\
\text { mililiter } \\
\text { Lengkuas } 2 \\
\text { cm } \\
\text { Garam dan } \\
\text { gula pasir qs } \\
\text { Kemangi } 2 \\
\text { tangkai } \\
\text { Cabai merah } 3 \\
\text { buah } \\
\text { Cabai hijau } 1 \\
\text { buah } \\
\text { Minyak } 2 \\
\text { sendok }\end{array}$ & $\begin{array}{l}\text { Labu } \\
\text { kuning : } \\
\text { protein } 1,1 \\
\text { gram, air } \\
9,1 \text { gram, } \\
\text { dan lemak } \\
0,3 \text { gram }\end{array}$ \\
\hline $\begin{array}{l}\text { Sayur } \\
\text { Lebui } \\
\text { Daun } \\
\text { Melinjo } \\
\text { Muda }\end{array}$ & $\begin{array}{l}\text { Lebui } 200 \\
\text { gram } \\
\text { Bawang } \\
\text { muda } \\
\text { Daun } \\
\text { melinjo } 2 \\
\text { ikat } \\
\text { Air } 2 \text { liter } \\
\text { Cabai rawit } 6 \\
\text { buah }\end{array}$ & $\begin{array}{l}\text { Bawang putih } \\
4 \text { siung } \\
\text { Bawang } \\
\text { merah } 6 \text { siung } \\
\text { Tomat } 2 \text { buah } \\
\text { Lengkuas } 2 \\
\text { cm } \\
\text { Garam dan } \\
\text { gula pasir qs }\end{array}$ & $\begin{array}{l}\text { Daun } \\
\text { melinjo } \\
\text { muda: } \\
\text { protein } 5 \\
\text { gram, air } \\
70,8 \text { gram, } \\
\text { dan lemak } \\
1,3 \text { gram }\end{array}$ \\
\hline $\begin{array}{l}\text { Sayur } \\
\text { Lebui }\end{array}$ & $\begin{array}{l}\text { Lebui } 200 \\
\text { gram } \\
\text { Bawang } \\
\text { muda } \\
\text { Air } 2 \text { liter } \\
\text { Cabai rawit } 6 \\
\text { buah } \\
\text { Bawang } \\
\text { putih } 4 \text { siung }\end{array}$ & $\begin{array}{l}\text { Bawang } \\
\text { merah } 6 \text { siung } \\
\text { Tomat } 2 \text { buah } \\
\text { Lengkuas } 2 \\
\text { cm } \\
\text { Garam dan } \\
\text { gula pasir qs }\end{array}$ & - \\
\hline
\end{tabular}

\section{Penentuan Kadar Abu Total}

Sejumlah bahan yang telah dihaluskan ditimbang dalam krus porselin yang telah diketahui beratnya. Krus berisi sampel kemudian dipijarkan dalam tanur hingga diperoleh abu berwarna putih. Krus dan abu dimasukkan kedalam desikator kemudian berat ditimbang setelah dingin. Persentase kadar abu (\% b/b) sampel selanjutnya dihitung (Sudarmadji, et. al. 2010; Nielsen, $2010^{\text {b)}) . ~}$

\section{Penentuan Kadar Antosianin}

Sejumlah bahan yang telah dipreparasi sebelumnya ditimbang ke dalam labu tentukur $50 \mathrm{~mL}$ kemudian digenapkan dengan akuades. Sampel dengan volume tertentu dimasukkan dalam tabung reaksi kemudian masing-masing ditambahkan dapar kalium klorida 0,025 M dengan $\mathrm{pH} 1$ dan natrium asetat dengan $\mathrm{pH}$ 4.5. Setelah didiamkan, absorbansi kedua perlakuan diukur pada panjang gelombang 520 $\mathrm{nm}$ dan $700 \mathrm{~nm}$ dan kadar antosianin (sianidin-3 glukosida ekivalen dengan $\mathrm{mg} / 100$ g) dihitung (Lee, 2005).

\section{Uji Kesukaan}

Uji kesukaan menggunakan uji hedonik dengan panelis non terstandar lebihdari 30 orang. Pengujian dilakukan ketika panelis tidak dalam keadaan lapar atau kenyang yakni pukul 14.00-16.00 WITA. Sebelum uji dimulai dilakukan penyuluhan mengenai uji kesukaan disertai permintaan informed consent.

Panelis menempati tempat yang telah disediakan dan mengisi data diri dalam borang. Pasca penetralan rongga mulut dengan air matang, panelis menguji sampel. Penilaian dilakukan dengan mengurutkan kesukaan terhadap sampel yang diujikan. Panelis dapat mencicip berbagai sampel jika ragu terhadap penilaian yang dilakukan. Panelis tidak diperkenankan memberikan skor yang sama. Data dianalisa via ANOVA dan uji lanjut LSD (Badan Standardisasi Nasional, 2006)

\section{HASIL DAN PEMBAHASAN}

Hasil determinasi Laboratorium Taksonomi, Struktur, dan Perkembangan Tumbuhan Jurusan Biologi FMIPA UNIBRAW menunjukkan bahwa tumbuhan yang diperoleh adalah lebui atau G/ycine max (L.) Merill. Hasil analisa proksimat disajikan dalam Tabel 2.

Tabel 2. Komposisi Kimia Lebui dan Produk Olahan

\begin{tabular}{lccccc}
\hline \multirow{2}{*}{ Komposisi } & Lebui & \multicolumn{4}{c}{ Produk Olahan Sayur Lebui } \\
\cline { 3 - 6 } & Lebui & Melinjo & $\begin{array}{c}\text { Daging } \\
\text { Sapi }\end{array}$ & $\begin{array}{c}\text { Labu } \\
\text { Kuning }\end{array}$ \\
\hline $\begin{array}{l}\text { Kadar air } \\
\text { (\%) }\end{array}$ & 11,36 & 10,68 & 11,98 & 10,62 & 10,67 \\
$\begin{array}{l}\text { Kadar abu } \\
\text { (\%) }\end{array}$ & 4,11 & 4.15 & 3.46 & 4.14 & 3,81 \\
$\begin{array}{l}\text { Kadar } \\
\text { antosianin } \\
\left(\begin{array}{l}\text { mg/100 } \\
\text { gr) }\end{array}\right.\end{array}$ & 46,76 & 10,02 & 23,37 & $\begin{array}{c}\text { Tidak } \\
\text { terdeteksi }\end{array}$ & 30,05 \\
\hline
\end{tabular}


Berdasarkan perbandingan terhadap studi sebelumnya pada kedelai hitam varietas Mallika (Nurrahman, 2005), kadar air lebui dalam studi memiliki nilai yang sedikit lebih tinggi dibandingkan dengan kedelai hitam Mallika. Kadar antosianin lebui juga jauh lebih rendah dibandingkan dengan kedelai hitam Mallika. Penggilingan dengan mesin memberikan efek panas cukup tinggi pada kulit biji lebui sehingga diasumsikan dapat merusak antosianin. Peningkatan suhu hingga $65-90{ }^{\circ} \mathrm{C}$ dapat menyebabkan degradasi hanya dalam waktu singkat (Welch, et.al, 2008).

Komposisi kimia produk olahan sayur lebui cukup bervariasi. Kadar air sedikit lebih tinggi pada varian sayur melinjo. Kadar abu daun melinjo lebih rendah dibandingkan dengan ketiga varian lain. Kadar abu terkait dengan jumlah mineral yang terkandung dalam olahan tersebut. Kadar antosianin produk olahan mengalami penurunan dibandingkan dengan lebui non olahan. Proses pemasakan dengan air mendidih dapat menurunkan kadar antosianin dalam olahan. Kadar antosianin pada varian daging sapi tidak terdeteksi dapat disebabkan oleh banyaknya matriks yang terkandung dalam olahan meski dilakukan faktor pengenceran berkali-kali. Kadar antosianin labu kuning dan melinjo jauh lebih tinggi dibandingkan dengan lebui dimungkinkan karena adanya tambahan antosianin dari labu dan melinjo. Labu kuning memiliki kandungan protoantosianidin, antosianin yang mungkin terekstraksi dalam produk olahan (Oloyede, et. al., 2014).

Panelis yang terlibat dalam uji kesukaan diperoleh sebesar 71 lembar informed consent dari 75 orang dengan 4 orang termasuk kriteria eksklusi berupa kesalahan dalam pengisian borang penilaian. Dari empat parameter sensori yang diujikan parameter warna tidak berbeda secara signifikan pada aras kepercayaaan $5 \%$ dengan parameter lain. Pada parameter rasa, sayur lebui berbeda bermakna pada aras kepercayaan $5 \%$ dengan ketiga varian produk lain. Varian melinjo memiliki rasa yang berbeda bermakna pada aras kepercayaan yang sama dengan varian labu kuning. Varian melinjo dan daging sapi tidak berbeda bermakna dengan varian labu kuning. Sayur lebui paling disukai dari keempat varian. Rasa enak dimiliki oleh sayur melinjo sementara rasa kurang enak dimiliki oleh varian sapi dan labu kuning.
Ditinjau dari parameter aroma, varian melinjo berbeda bermakna pada aras kepercayaan $5 \%$ terhadap daging sapi dan labu kuning, namun tidak berbeda bermakna pada sayur lebui. Sayur lebui tidak berbeda bermakna dengan labu kuning, demikian pula antara varian daging sapi. Dengan demikian dari hasil rerata dapat disimpulkan bahwa varian melinjo dan lebui memiliki aroma paling harum sementara varian sapi dan labu kuning memiliki aroma yang harum.

Berdasarkan hasil analisis dari parameter tekstur, bahwa sayur lebui berbeda secara bermakna pada aras kepercayaan 5\% terhadap ketiga varian lainnya. Demikian pula pada varian melinjo dan daging sapi berbeda bermakna dalam hal tekstur. Perbedaan tak signifikan ditemukan antara varian melinjo dan daging sapi terhadap labu kuning. Tekstur paling baik menurut panelis diperoleh pada sayur lebui, kemudian disusul baik oleh varian melinjo dan kurang baik oleh dua varian lain meliputi sapi dan labu kuning.

\section{KESIMPULAN}

Berdasarkan penelitian yang telah dilakukan dapat disimpulkan bahwa analisis kadar air, abu dan antosianin lebui dan produk olahan menunjukkan komponen kimia dengan kadar yang serupa terkecuali antosianin. Kadar antosianin pada produk olahan sayur bervariasi namun mengalami trend penurunan. $\mathrm{Uji}$ kesukaan menunjukkan bahwa warna antar varian tidak berbeda, sementara sayur lebui memiliki tekstur, aroma dan rasa yang paling baik. Hasil penelitian ini bersifat preeliminari sehingga disarankan untuk dilakukan penyempurnaan dalam metode analisis sesuai dengan jenis sampel yang digunakan terkait keberadaan alat dan bahan. Kondisi optimal dalam pelaksanaan uji sensori berupa persyaratan ruangan sesuai dengan SNI dan perbaikan formula sebagai upaya pengembangan perlu dioptimalkan sehingga meningkatkan akurasi hasil yang diperoleh

\section{DAFTAR PUSTAKA}

Astadi IR., AstutiM, SantosoU, dan Nugraheni PS. 2009. In vitro antioxidant activity of anthocyanins of black soybean seed coat in human low density lipoprotein (LDL). Food Chemistry, 112 (3): 659663. 
Astadi IR dan Paice AG. 2011. Black soybean (Glycine max L. Merill) seeds antioxidant capacity. Dalam: Preedy VR, Watson RR, dan Patel VP. Nuts and Seed in Health and Disease Prevention. Elsevier. Oxford. 229-236

Badan Standardisasi Nasional. 2006. Standar Nasional Indonesia 01-2346-2006 Petunjuk Pengujian Organoleptik Dan Atau Sensori. Badan Standardisasi Nasional 3-137.Jakarta.

Lee J, Durst RW, Wrolstad RE. 2005. Determination of total monomeric anthocyanin pigment content of fruit juices, beverages, natural colorants, and wines by the ph differential method: collaborative study.JAOAC International, 88 (5): 1269-1278.

Nielsen SS ${ }^{\text {a) }}$ 2010. Food Analysis. Fourth Edition. Springer. New York: 108, 122$125,139-142$.

Nielsen SS ${ }^{\text {b) }}$. 2010. Food Analysis Laboratory Analysis Second Edition. Springer. New York. 19-21.
Nurrahman. 2015. Evaluasi komposisi zat gizi dan senyawa antioksidan kedelai hitam dan kedelai kuning. Jurnal Aplikasi Teknologi Pangan 4 (3): 89-93.

Oloyede FM, Adebooye OC. dan Obuotor EM. 2014. Planting date and fertilizer affect antoxidants in pumpkin fruit. Scientia Horticulturae, 168: 46-50

Sudarmadji S, HaryonoB, danSuhardi. 2010. ProsedurAnalisaUntukBahanMakanan Dan Pertanian. Yogyakarta. 83, 99, 100.

Welch CR, Wu Q, dan Simon JE. 2008. Recent Advances in Anthocyanin Analysis and Characterization. Curr

http://www.suaradesa.com/berita/2016/03/12/ marwan-ketahanan-pangan-jadiprioritas-utama[20 Maret 2016 pukul 07.30].

http://www.rri.co.id/post/berita/134896/daera h/prevalensi_kurang_gizi_ntb_sebesar_2 57_persen.html[20 Maret 2016 pukul 07.30].

http://www.lombokpost.net/2016/03/01/menk es-sentil-gizi-buruk-ntb/ [20 Maret 2016 pukul 07.30]. 